\title{
Realisasi Program Dinas Sosial Kota Jambi dalam Membentuk Mental dan Keterampilan Anak Jalanan
}

\author{
Elvi Wahyu Jenia, Suryanef \\ Program Studi Pendidikan Pancasila dan Kewarganegaraan \\ Universitas Negeri Padang \\ E-mail: elviwahyujenia22@gmail.com
}

\section{ABSTRAK}

Artikel ini bertujuan untuk menjelaskan realisisasi program Dinas Sosial kota Jambi dalam membentuk mental dan keterampilan anak jalanan. Jenis penelitian kualitatif deskriptif. Sumber data yang digunakan adalah data primer dan data sekunder yang diperoleh melalui wawancara dan dokumentasi. Informan ditentukan secara purposive, beberapa informan penelitian yaitu Kepala Bidang Rehabilitasi Sosial, Kepala Seksi Rehabilitasi Sosial, Anak dan Lanjut Usia Dalam Dinas Sosial kota Jambi dan Dinas Satuan Polisi Pamong Praja kota Jambi. Hasil penelitian menunjukkan bahwa realisasi program Dinas Sosial kota Jambi dalam membentuk mental dan keterampilan anak jalanan tahun 2017-2018 cukup baik dalam melaksanakan pembinaan anak jalanan. Dalam program ini anak jalanan diberikan empat bentuk bimbingan yaitu bimbingan mental, fisik, sosial, dan keterampilan namun bimbingan keterampilan belum terealisasikan dengan baik. Hal ini disebabkan karena kurangnya kerja sama antara Dinas Sosial kota Jambi dengan masyarakat, kurangnya kesadaran diri pada anak jalanan dan keterbatasan dana sehingga program ini terkesan tidak berkelanjutan. Oleh karena itu pemerintah memberikan bantuan berupa uang dan peralatan yang dibutuhkan anak jalanan untuk membuka usaha.

Kata Kunci: Dinas Sosial, mental, keterampilan, anak jalanan, Jambi

\section{ABSTRACT}

This article is aims to explain how the realization of the program that carried out by the Jambi City Social Service in shaping the mental and skills of street children in 2017-2018. This research used descriptive qualitative methods. Data sources that have been used are primary and secondary data obtained through interviews and documentation. The informants in this study were determined by purposive sampling, some of the research informants are: the Head of Social Rehabilitation, the Head of the Social Rehabilitation Section, Children and Elderly in the Jambi City Social Service and the Jambi Municipal Civil Service Police Unit. The results showed that the realization of Social Service program in Jambi City shaping the mental and skills of street children in 2017-2018 was quite good in carrying out street children's development programs. In this program street children are given four forms of guidance, namely mental, physical, social, and skill guidance but the guidance of skills has not been fully realized. This is due to the lack of cooperation between the Jambi City Social Service and the community so that the program seems unsustainable. 
Keywords : social department, mental, skill, homeless people, Jambi province

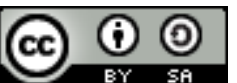

This work is licensed under the Creative Commons Attribution-ShareAlike 4.0 International License. (2019 by author.

\section{PENDAHULUAN}

Anak jalanan dibagi dalam tiga kelompok berdasarkan hubungan dengan orang tuanya, yaitu: pertama, anak yang putus hubungan dengan orang tuanya, tidak sekolah, dan tinggal di jalanan (anak yang hidup di jalanan); kedua, anak yang berhubungan tidak teratur dengan orang tuanya, tidak sekolah, kembali ke orang tuanya seminggu sekali, dua minggu sekali, dua bulan atau tiga bulan sekali, biasa disebut anak yang bekerja di jalanan ; ketiga, anak yang masih sekolah atau sudah putus sekolah, kelompok ini masuk kategori anak yang rentan menjadi anak jalanan (Herlina,2014).

Kementrian Sosial Republik Indonesia menjelaskan definisi anak jalanan sebagai anak yang melewatkan atau memanfaatkan sebagian besar waktunya untuk melakukan kegiatan sehari-hari di jalanan termasuk di lingkungan pasar, pertokoan dan pusat keramaian lainnya. Berdasarkan UU No.35 Tahun 2014 tentang perlindungan anak, pasal 1 ayat 1 "anak adalah seseorang yang belum berusia 18 (delapan belas) tahun, termasuk anak yang masih dalam kandungan". Jadi menurut UndangUndang No.35 Tahun 2014 Pasal 1 ayat 1, dapat dikategorikan umur anak berkisar dimulai dari baru lahir hingga usia 18 tahun. Rata-rata di Jambi mereka sering dijumpai berkelompok dan berumur dari 6 tahun sampai 18 tahun. Rentang usia ini seharusnya mendapatkan pendidikan yang layak serta kasih sayang dari orang tua, namun justru sebaliknya mereka sudah bekerja di jalanan. Menurut wawancara yang dilakukan dengn Bapak Drs.Jaharuddin,ME, Kepala Bidang Rehabilitasi Sosial, Dinas Sosial Kota Jambi, kegiatan yang sering dilakukan oleh anak jalanan ini biasanya mengamen di pinggir jalan raya, atau menjadi pengatur lalu lintas yang membantu mobil menyebrang atau berbelok di persimpangan dengan begitu maka mereka akan dibayar senilai seribu atau dua ribu rupiah. Beberapa lagi, ada yang mengemis, meminta belas kasihanan dari pengemudi yang berhenti pada saat lampu merah dan berjualan tisu di pinggir jalan. Dari hasil penelitian Erwin (2013) menunjukkan bahwa lamanya waktu anak jalanan melakukan kegiatan di jalanan sekitar delapan sampai dengan 12 jam (54\%).

Bapak Drs. Jaharuddin, ME sebagai kepala bidang Rehabilitas Sosial di Dinas Sosial Kota Jambi menjelaskan bahwa anak-anak tersebut setelah melalui proses penjaringan kemudian akan dilatih fisik, spriritual, kejiwaannya serta keterampilannya selama tiga sampai empat hari. Untuk melatih fisik anak jalanan Dinas Sosial bekerja sama dengan Batalyon 142 Kesatria Jaya. Dalam pelatihan ini, anak jalanan dididik dengan disiplin, latihan fisik seperti sit up, push up dan lari. Selain itu didikan militer ini yang membentuk fisik akan memberikan efek jera kepada anak jalanan yang sudah terjaring untuk tidak kembali ke jalanan lagi. Kemudian didikan selanjutnya adalah pendidikan kerohanian. Anak jalanan akan 
Volume 2 No. 52019

diberikan pelajaran dan sikap spiritual sesuai dengan agamanya masingmasing. Bagi yang beragama Islam, mereka akan diajarkan mengaji, sholat lima waktu berjamaah, sholat tahajud dan mendengarkan ceramah. Mereka didampingi oleh ustad yang sukarela memberikan ilmunya sehingga dari kegiatan ini akan sedikit membantu membentuk jiwa spiritual anak jalanan untuk terus melakukan ibadah dan dilarang melakukan perbuatan dosa. Kemudian pendidikan selanjutnya mereka dilatih mental dan kejiwaannya. Dalam hal ini juga dianalisis faktor yang membuat mereka turun ke jalanan. Pendidikan ini dilakukan oleh psikolog yang sukarela dalam membina anak jalanan.

\section{Undang Undang Dasar} Republik Indonesia 1945 pasal 34 ayat (1) mengatakan bahwa fakir miskin dan anak jalanan dipelihara oleh negara. Jadi negara bertanggung jawab dalam melindungi, mensejahterakan, merawat, memberikan pendidikan dan mengembangkan kemampuan anak. Negara berkewajiban dalam bidang kesejahteraan sosial, untuk mewujudkan Indonesia sebagai negara kesejahteraan sehingga rakyat dapat hidup sesuai harkat dan martabat kemanusiaan. Pemerintah Kota Jambi memberikan perlindungan kepada anak jalanan melalui Peraturan Walikota No.29 Tahun 2016 tentang penanganan gelandangan, pengemis (gepeng) dan anak jalanan. Melalui program ini, Dinas Sosial Kota Jambi menanggulangi anak jalanan melalui rehabilitasi sosial.

Pembinaan yang diterapkan selama ini dalam berbagai bidang belum terealisasikan dengan optimal seperti yang diharapkan. Ada beberapa hal yang memerlukan penyempurnaan seperti mekanisme perencanaan program, kualitas pelayanan, keterbatasan Sumber Daya Manusia (SDM) dan pengembangan alternatif program pelayanan yang lebih responsif terhadap kebutuhan anak jalanan.

Berdasarkan alasan diatas, permasalahan ini perlu diteliti untuk mengetahui bagaimana realisasi progam yang sudah dilakukan Dinas Sosial Kota Jambi dalam menanggulangi permasalahan anak jalanan sehingga dapat diketahui kendala dan kelebihan dari program ini. Penelitian ini juga bertujuan untuk mengetahui upaya yang harus dilakukan oleh pemerintah guna meningkatkan program Dinas Sosial dalam menanggulangi anak jalanan.

\section{METODE PENELITIAN}

Metode penelitian yang digunakan adalah deskriptif kualitatif. Penelitian ini dilakukan di Dinas Sosial Kota Jambi khususnya bidang Rehabilitasi Sosial sebagai penanggung jawab program anak jalanan. Penelitian ini juga dilakukan di Dinas Satuan Polisi Pamong Praja (Satpol PP) Kota Jambi sebagai instansi penanggungjaab sebelum mereka diserahkan pada Dinas Sosial Kota Jambi. Untuk mendapatkan informasi yang lebih akurat dari anak jalanan yang belum melalui proses pembinaan oleh Dinas Sosial kota Jambi, maka peneliti juga terjun langsung ke lapangan seperti persimpangan jalan maupun tempat yang biasanya menjadi titik kumpul anak jalanan tersebut. Jenis data yang digunakan adalah jenis data Primer dan data Sekunder. Teknik pengumpulan data menggunakan metode observasi, 
wawancara dan dokumentasi. Untuk menguji keabsahan data, penulis menggunakan metode triangulasi data. Teknik analisis data dalam penelitian ini terdiri dari tiga komponen yaitu reduksi data, penyajian data, dan verifikasi (penarikan kesimpulan).

\section{HASIL DAN PEMBAHASAN}

Realisasi Program Dinas Sosial Kota Jambi Dalam Membentuk Mental Dan Keterampilan Anak Jalanan (Kajian Terhadap Program Tahun $\underline{\text { 2017-2018) }}$

Program pembinaan anak jalanan Dinas Sosial kota Jambi bertujuan untuk mencegah dan mengantisipasi bertambah suburnya anak jalanan serta mendidik mereka agar dapat hidup secara layak dan normal sebagaimana masyarakat pada umumnya. Hasil dari evaluasi program Dinas Sosial Kota Jambi dalam pembinaan anak jalanan, terdiri dari beberapa indikator yaitu: indikator masukan, indikator proses, dan indikator pengeluaran (Elvira, 2017).

a. Indikator Masukan merupakan bahan-bahan dan sumber daya yang digunakan untuk mengimplementasikan kebijakan. Bahan - bahan dan sumber daya yang dipersiapkan oleh Dinas Sosial Kota Jambi dalam pelaksanaan program adalah susunan program yang dirancang sesuai jangka waktu yang telah ditargetkan. Selain itu, sumber daya manusia dan sumber daya dana yang cukup dalam merealisasikan program tersebut juga menjadi bagian dari indikator masukan. Untuk melaksanakan program pembinaan anak jalanan oleh Dinas Sosial Kota Jambi ini dapat dikatakan persiapan yang dilakukan sudah cukup baik, namun ada beberapa rencana yang tidak sesuai dengan proses pelaksanaan pembinaan seperti dana yang tidak sesuai target serta sumber daya manusia yang masih terbatas untuk membina keterampilan anak jalanan.

b. Indikator Proses adalah panduan antara cara pelaksanaan dengan bahan-bahan yang sudah dipersiapkan dalam merealisasikan program pembinaan anak jalanan sesuai dengan program yang sudah dirancang. Dalam pelaksanaan program ini terdapat tiga bentuk usaha yang dilakukan dalam proses pelaksanaannya yaitu; usaha preventif, represi dan rehabilitasi sosial. Pertama, usaha preventif dilakukan oleh orang yang bertugas melakukan pengawasan patroli keliling di kota Jambi. Patroli ini dilakukan oleh Dinas Satpol PP, Dinas sosial maupun polisi yang bertanggung jawab untuk melakukan pengawasan.

Selain patroli yang dilakukan oleh instansi terkait, penncegahan juga dilakukan dengan melakukan sosialisasi kepada masyarakat maupun sekolah untuk mencegah munculnya anak jalanan. Kedua, usaha represif. Dalam usaha ini dilakukan penjaringan terhadap anak jalanan dengan instansi terkait. Setelah itu dilakukan penahanan anak jalanan untuk proses identifikasi dan penyeleksian. Dalam proses represif ini, pelaksanaannya masih belum baik karena kurangnya kerjasama yang dilakukan dengan psikolog untuk pemeriksaan mental anak. Hal ini berpengaruh terhadap proses penyeleksian tahap rehabilitasi. Ketiga, usaha rehabilitasi sosial. Dalam 
mengembangkan kemampuan sosial, mental dan spiritual anak jalanan, kondisi anak jalanan membutuhkan sentuhan yang intensif sebab mereka masih memiliki kesempatan yang luas untuk mengembangkan pola pikir, rasa, dan perilaku, seiring dengan pertumbuhan fisiknya (Herlina, 2014). Dibutuhkan lingkungan yang sehat, terutama pola asuh orang tua agar anak tidak kehilangan arah dalam pergaulannya dan mampu memenuhi kebutuhan fisik dan psikisnya.

Dalam usaha rehabilitasi anak jalanan pada Dinas sosial Kota Jambi, anak diberikan empat bimbingan yaitu bimbingan mental, fisik, sosial dan keterampilan.

Berdasarkan wawancara yang penulis lakukan, tidak semua bimbingan terealisasikan dengan baik karena terkendala waktu dan sumber daya manusia. Selain itu, Dinas Sosial kota Jambi juga belum melakukan kerjasama yang baik dengan masyarakat, pengusaha dan organisasi masyarakat yang bergerak dalam bidang keterampilan. Selain itu, kebutuhan dana yang besar juga menjadi kendala. Jika pembinaan dilakukan dalam jangka panjang maka dana yang diperlukan juga besar sehingga bimbingan keterampilan masih belum terealisasikan dengan baik.

c. Indikator Keluaran adala barang atau pelayanan yang diproduksi oleh suatu program yang dimulai dari input (persiapan) serta proses (cara pelaksanaan) yang sudah dipadukan (Elvira, 2017). Berdasarkan monitoring dan evaluasi oleh pemerintah daerah, program ini sudah berjalan dengan baik, namun ada beberapa hal-hal yang menjadi kendala seperti dana yang terbatas dan kurangnya tenaga ahli dalam membimbing bidang pembelajaran yang sudah ditentukan.

d. Indikator Dampak merupakan hasil atau akibat yang ditimbulkan oleh suatu program (Elvira, 2017). Dampak yang diharapkan dari program ini adalah adanya peningkatan kesejahteraan masyarakat. Namun dari hasil pembinaan yang terbilang tidak efektif, yang terjadi adalah sebaliknya, yaitu dapat berdampak buruk pada anak jalanan. Pembinaan yang belum terealisasikan dengan sepenuhnya tidak akan berpengaruh pada anak jalanan. Setelah proses pembinaan, mereka cenderung akan kembali ke jalanan karena proses pembinaan yang jalan ditempat, dan tidak berkesan. Setelah proses pembinaanpun mereka tidak membawa bekal keterampilan yang sangat dibutuhkan dalam dunia pekerjaan.

\section{Terdapat tiga tahap pembinaan yaitu:}

1. Tahap penyadaran dan pembentukan perilaku. Dalam tahap ini dapat membentuk anak untuk sadar dan peduli akan peningkatan kapasitas diri. Dalam tahap ini anak dapat belajar dari pengalaman, selain itu dalam pembentukan perilaku diperlukan motivasi agar anak dapat mencapai kesuksesannya. Apabila anak tidak termotivasi maka anak cenderung malas dan tidak semangat. Dalam penelitian ini pembinaan yang dilakukan untuk menyadarkan dan membentuk perilaku anak jalanan, dinas sosial melakukan pembinaan fisik pada anak jalanan. Pembinaan ini dibimbing oleh anggota TNI untuk membina fisik anak jalanan sehingga mereka terlatih untuk disiplin dan memiliki tubuh yang sehat. Namun 
tidak hanya kesehatan jasmani saja anak jalanan ini juga diperhatikan kesehatan rohani. Untuk memastikan mental anak jalanan sehat maka Dinas Sosial juga melakukan bimbingan mental yang dilakukan oleh psikolog serta ustadz. Bimbingan ini bertujuan untuk memperbaiki mental anak yang akan berpengaruh pada perilaku anak ke depannya.

2. Tahap transformasi kemampuan dimana dalam tahap ini adalah pemberian pendidikan, wawasan, dan pengetahuan pada anak. Dalam program pembinaan anak jalanan ini anak masih sedikit menerima wawasan atau pendidikan yang diberikan oleh Dinas Sosial kota Jambi.

3. Tahap peningkatan kemampuan adalah tahap peningkatan inisiatif dan inovatif pada anak sehingga mereka dapat mandiri. Berdasarkan temuan di lapangan, kemampuan anak jalanan masih sangat minim baik itu dalam segi pengetahuan maupun keterampilan sehingga membuat mereka serba terbatas dalam menyalurkan kemampuannya untuk bekerja.

Kendala Dalam Realisasi Program Dinas Sosial Kota Jambi Dalam Membentuk $\quad$ Mental dan Keterampilan Anak Jalanan Tahun 2017-2018

a. Kurangnya Kerja Sama

Fathoni

(2006:24) mengungkapkan, organisasi formal memiliki tugas resmi sesuai dengan peraturan yang telah ditentukan. Organisasi formal tidak dapat memenuhi hasrat dan perasaan para anggota pekerja dalam suatu organisasi karena adanya peraturan yang mutlak. Setiap orang memiliki batas tugas masing masing sesuai bidang kemampuannya, meskipun tugasnya berbeda bukan berarti tugas tersebut berdiri sendiri melainkan adanya kerjasama antar bidang. Jika dikaitkan dengan teori diatas, Dinas sosial Kota Jambi merupakan organisasi formal yang memiliki tugas resmi yang terikat dengan peraturan sehingga tidak bisa bertindak bebas. Namun dalam hal kerja sama untuk melaksanakan program pembinaan anak jalanan ini, dinas sosial diberikan kebebasan untuk bekerjasama dengan masyarakat, organisasi nonformal ataupun dunia usaha.

Kenyataannya dari hasil penelitian kerja sama yang dilakukan dengan masyarakat masih sangat minim yang mengakibatkan program ini tidak berkelanjutan. Jika anak tersebut terampil, mereka bisa melakukan sebuah usaha atau bekerja tanpa harus kembali ke jalanan lagi.

b. Kurangnya kesadaran diri pada anak jalanan

Pada umumnya anak jalanan identik dengan kerusakan mental yang berasal dari faktor keluarga maupun faktor pergaulan atau lingkungan sekitarnya. Anak memilih bekerja karena kurangnya makanan yang ada di rumah. Beberapa dari mereka meninggalkan rumah dan menjadi anak jalanan, dan biasanya berasal dari keluarga yang kasar dan kurangnya keharmonisan dalam keluarga (Puruhita, 2016). Keputusan yang diambil anak jalanan bukan sematamata berdasarkan motif ekonomi, melainkan pilihan rasional dalam upaya memenuhi kebutuhan hidupnya (Indarto, 2009). Tahap penyadaran dan pembentukan perilaku anak membutuhkan motivasi 
agar mereka dapat mencapai kesuksesannya, karena apabila anak tidak termotivasi maka cenderung malas dan tidak bersemangat.

Berdasarkan dari hasil penelitian yang dilakukan, kurangnya perhatian orang tua dan orang tua yang bercerai dapat mengakibatkan anak rentan untuk kembali ke jalanan. Ditambah lagi dengan pembinaan yang dilakukan oleh Dinas Sosial Kota Jambi yang masih belum optimal dalam menangani permasalahan anak jalanan.

\section{c. Keterbatasan Dana}

Dana merupakan suatu sumber daya yang penting sebagai penunjang untuk berjalannya sebuah program. Dalam program pembinaan anak jalanan ini dana yang minim menjadi kendala usaha melakukan rehabilitasi sosial kepada anak jalanan. Hal ini berhubungan dengan pembinaan yang seharusnya dilakukan oleh pembimbing yang sesuai dengan bidangnya. Namun karena keterbatasan dana, maka pembimbing anak jalanan hanya dilakukan secara sukarela. Dalam menjalankan bimbingan keterampilan ini juga membutuhkan tambahan waktu selama pembinaan sehingga dana yang dibutuhkan juga bertambah.

Sama halnya dengan hasil penelitian Tarwilah (2013) yang mengungkapkan bahwa pelayanan pendidikan anak jalanan masih minim, karena ada persoalan keterbatasan sumber daya, baik sumber daya manusia maupun sumber daya keuangan. Kondisi ini juga membawa masalah tersendiri dalam memberikan pelayanan pendidikan bagi anak jalanan. Jika tidak hati-hati, anak jalanan yang bergabung di sekolah singgah akan lari dan kembali ke jalan.

Upaya Dinas Sosial Kota Jambi dalam Merealisasikan Program

Pembentukan Mental dan

Keterampilan Anak Jalanan Tahun $\underline{\text { 2017-2018 }}$

a. Sosialisasi ke sekolah dan ke masyarakat untuk pencegahan kenakalan anak.

Dalam upaya mencegah dan mengantisipasi munculnya anak jalanan maka pemerintah kota Jambi melalui Dinas Sosial kota Jambi melakukan sosialisasi guna mencegah kenakalan anak. Sosialisasi ini dilakukan ke sekolah-sekolah dan ke masyarakat yang bertujuan untuk menginformasikan kepada anak anak yang masih berusia 6-18 tahun untuk tidak salah mengikuti pergaulan. Di usia anak yang rentan ini tentunya mereka selalu mengikuti hal-hal yang membuat mereka senang tanpa memikirkan dampaknya.

Sosialisasi yang dilakukan ke sekolah oleh Dinas Sosial kota Jambi adalah dengan memberikan materi mengenai dampak dan bahaya apabila anak melakukan kegiatan di jalanan. Sementara itu, sosialisasi yang dilakukan ke masyarakat khususnya para orang tua bertujuan agar mengawasi anaknya dalam bergaul dan selalu memberikan perhatian lebih.

b. Pemberian bantuan kepada anak jalanan di kota Jambi

Untuk mencegah timbulnya anak jalanan maka Dinas Sosial melakukan pengawasan dan pemantauan terhadap anak jalanan di kota Jambi, pengawasan ini bertujuan untuk melihat apa yang melatar 
belakangi anak tersebut turun ke jalanan. Dinas sosial yang melakukan pengawasan juga terjun langsung untuk melakukan konseling kepada para orang tua anak jalanan. Apabila anak tersebut merupakan keluarga yang tergolong ekonomi lemah maka Dinas Sosial memberikan bantuan kepada masing-masing anak jalanan, baik itu berupa uang maupun peralatan seperti gerobak agar mereka dapat berjualan tanpa harus mengemis atau mengamen di jalanan. Usaha lainnya yang dilakukan oleh LSM (Lembaga Swadaya Masyarakat) adalah beasiswa pendidikan dan pelatihan keterampilan untuk anak jalanan di Kota Jambi (Zarfina, 2008).

\section{SIMPULAN}

Berdasarkan Peraturan Walikota Nomor 29 Tahun 2016 tentang Penanganan Gelandangan, Pengemis (GEPENG) dan Anak Jalanan, serta hasil temuan yang telah peneliti dapatkan dapat disimpulkan bahwa realisasi program Dinas Sosial kota Jambi dalam membentuk mental dan keterampilan anak jalanan pada tahun 2017-2018 belum terealisasikan dengan baik. Diantaranya teknis penyeleksian anak jalanan yang tidak sesuai dengan aturan telah memberikan dampak pada pembinaan yang terkesan percuma pada anak jalanan.

Bimbingan keterampilan terkendala dengan kurangnya sumber daya manusia dalam melakukan pembinaan kepada anak jalanan serta sumber daya dana yang minim membuat program menjadi tidak efektif. Waktu pembinaan yang singkat tentunya berpengaruh dalam membentuk mental dan keterampilan anak jalanan. Selain itu, kerja sama yang dilakukan antara dinas sosial kota Jambi dengan masyarakat masih terbatas, sehingga membuat program ini tidak berkelanjutan. Kesadaran diri anak jalanan yang masih rendah membuat mereka tidak berubah dan kembali ke jalanan.

\section{DAFTAR PUSTAKA}

Astri, Herlina. (2014). Kehidupan Anak Jalanan di Indonesia: Faktor Penyebab,Tatanan Hidup dan Kerentanan Berprilaku Menyimpang. Pusat Pengkajian, Pengelolaan Data dan Informasi: Sekretariat Jendral RI.

Destia,Elvira. (2017). Evaluasi Program Anak Jalanan di LSM Komunitas Peduli Anak di Kampung Aur Medan. Skripsi. Medan: Universitas Sumetera Utara.

Erwin. (2013). Karakteristik Anak Jalanan dan Bentuk Bentuk Kekerasan Terhadap Anak Jalanan di Kota Padang Provinsi Sumatera Barat: Universitas Andalas.

Fathoni,Abdurrahmat. (2006). Organisasi Dan Manajemen Sumber Daya Manusia. Jakarta: PT. Rineka Cipta.

Indarto, Setyo, Sigit. (2009). Strategi Hidup Anak Jalanan. Universitas Negeri Yogyakarta.

Pamuchtia Yunda, Nurmala. (2013). Konsep Diri Anak Jalanan. Jurnal Transdisiplin Sosiologi. Jawa Barat.

Peraturan Walikota Nomor 29 Tahun 2016 (Penanganan gelandangan, pengemis dan anak jalanan).

Puruhita dkk. (2016). Perilaku Sosial Anak Anak Jalanan di Kota 
Semarang: Univerritas Negeri Semarang.

Tarwilah. (2013). Pendidikan keagamaan Pada Komunitas Anak Jalanan Kota Banjarmasin. IAIN Antasari.

UU No.35 Tahun 2014 (Perlindungan anak).

UUD 1945 Pasal 34 ayat (Kemiskinan).

Zarfina, Yenti dkk. (2008). Anak Jalanan di Simpang Lampu Merah Telanaipura Kota Jambi (analisis Terhadap Dampak Eksploitasi Anak). IAIN Sulthan Thaha Saifuddin Jambi 